\title{
Review
}

\section{Becoming who we are: Politics and practical philosophy in the work of Stanley Cavell}

\author{
Andrew Norris \\ Oxford University Press, Oxford, 2017, xii+328 pp., \\ ISBN: 9780190673949
}

Contemporary Political Theory (2020) 19, S239-S242. https://doi.org/10.1057/s41296019-00354-8; published online 15 October 2019

For many political philosophers, Stanley Cavell is a thinker of marginal importance - well-known but elusive, provocative but eccentric. His writing, it is said, is difficult, overly literary, and perhaps simply too self-involved. Hence, amongst his advocates, it is a familiar regret that he is referred to rather than read. This is a pity and also something of an irony, given the importance that is attached to reading in his work, an importance that he sees in political terms. The significance of reading lies not in scholarly coverage of vast ranges of literature but rather in giving attention to a text, in being ready to be challenged by it, and in taking on the responsibilities of interpretation. Cavell's own texts are compellingly intertextual, always beginning in response. Their demands upon the reader arise not from their exploitation of a specialised vocabulary, as, say, in Martin Heidegger's work, nor from the intricate densities of their argument, as, say, in John McDowell's, but rather from the invitation to think.

Such qualities can mean that there is no obvious starting point with his work, and it may seem that there is no way in. Yet, The Senses of Walden (1972), Cavell's 'little book' on Walden, does in some degree present a microcosm of his work as a whole. Written in a period of some 6 weeks in the summer of 1971, when the Vietnam War was moving towards its denouement, and inserted at something like a mid-point in the 16 years that it took him to complete his most central work, The Claim of Reason (1979), this short text takes up themes that run throughout his writings and, in emulating Thoreau's partly allegorical text, presents these in a manner that is at once accessible and an incitement to further thought. It is one of the striking features of Andrew Norris's Becoming Who We Are that it gives Walden so central a place.

Norris has already done as much as anyone to show the political importance of Cavell's work, and his earlier collection, The Claim to Community (2006), included many fine essays, as well as a set of responses from Cavell. But those were essays - a collection of well-considered and nicely complementary pieces but

(c) 2019 Springer Nature Limited. 1470-8914 Contemporary Political Theory Vol. 19, S4, S239-S242 
separate forays into the subtleties of Cavell's engagement - whereas here, in this monograph, there is a sustained account that draws together different aspects of the work and develops with impressive conviction. The argument moves from a sensitive analysis of Cavell's inheritance of ordinary language philosophy and Wittgenstein, through an exploration of community and voice, and towards an affirmation of the conditions and aspirations of democracy. A careful line is drawn in differentiating Cavell thinking from liberalism in its familiar forms, and from the enormously influential philosophy of John Rawls, Cavell's Harvard colleague over a period of almost 50 years. Rousseau's influence and the inheritance from Kant are felt keenly and recurrently in the text, and an endorsement of autonomy, albeit in a qualified form, comes to the fore in conclusion.

The discussion of ordinary language philosophy in Chapter 1 is striking not only for its nuanced coverage of the topic but also and especially for its emphasis on the new departure that Cavell brings about. While accomplished commentators such as Stephen Mulhall and Espen Hammer have rightly emphasised Cavell's inheritance of J.L. Austin, they do not go far enough, on Norris's view, in showing the manner in which Cavell departs from his teacher. The encounter with Austin 'sets the stage', Norris claims, for all that comes after. Our access to the ordinary requires philosophical attention to 'what we say when', but Cavell turns this insight in a new direction: 'Austin had not adequately appreciated the uncanny nature of the fact that our access to the ordinary is not immediate and unreflective but requires philosophical work, work that challenges our philosophical and cultural inheritance' (pp. 17-18).

The title of Cavell's masterwork, The Claim of Reason, signals reasonably clearly that the concept of a claim is pivotal for his political thought. Its double genitive expresses both the claims that reason makes on me and the importance of my claiming of reason - that is, reason's and my own dependence upon this firstperson affirmation and essaying of thought. Norris deftly demonstrates the theme's pertinence to the question of authority: 'one claims to speak authoritatively for the community, and does so on the basis of no independent source of impersonal authority. The authority one claims can only be exercised in an act that grants the same authority to those whom one addresses: one asserts oneself to be, with them, a speaker among speakers, a citizen among equals' (pp. 114-115).

The performative nature of the 'we' in ordinary language philosophy's 'what we say when', as in any declaration of independence, is related, Cavell suggests, to the authority one has in declaring one's promises or intentions. This points to a democratic politics that is plainly other than the aggregation of individual preferences that Milton Friedman imagines. Moreover, in contrast to Rawls' emphasis on cooperation in the realisation of our shared projects, and at a distance from the extolling of dialogue by, for example, Richard Bernstein, Cavell stresses the importance of conversation. The second syllable of 'conversation' indicates its turning of thought: a remark sparks a thought that takes a new direction, or meets 
with a rebuff, or achieves assent, partial though this will usually be. Conversation is not a negotiation to realise my already conceived individual or collaborative projects but rather the means of finding what those projects might be.

Seeking community, a claim in Cavell's sense $i s$ made by an individual, but it is made by her 'to express an aspect of herself and of her will that is shared by others. The political claim, like the claim of the ordinary language philosopher, is a claim that must by its very nature be made in the first-person plural - that is, for the other whom one addresses; but it is, as such, also made for the one uttering it' (pp. 115-116). That this is also for the one uttering it is crucial, for this is not a matter of the positing of a democratic virtue of altruism but rather an articulation of what it is to be a human being, of the structuring of its necessities, and it is right to find in this a notion of autonomy. It is in offering my voice to community, in testing out my judgements, in seeking mutual attunement, in risking the rebuff, that my best prospects for my own autonomy consist.

But there is reason for some slight reservation about the manner in which Norris leaves the reader with these thoughts, with an emphasis on autonomy that is almost bound to be read in terms of the well-worn paths of argument that have characterised so much liberal political theorising. The different landscape that Cavell's prose describes provides fertile ground for the retrieving of this notion; the more familiar territory that comes into view in Norris's consistently elegant but less stylised writing perhaps does not achieve this - or not quite. So it is worth reaffirming the efforts Norris does make to pull his reader away from those wellworn paths.

Early in the book, he sketches notions of Emersonian partiality, and late in the text these come through with precision and power. Partially, for Emerson, and the shameful experience of lack, for Cavell, are preconditions for transformation not from but of the conformity of everyday life as it is now lived (p. 207). The friend as a metonym of this relation - serves me well when she provokes me, drawing me on to some next and better possibility of myself. Received conceptions of autonomy fail to register 'this necessary moment of negativity,' where the role of the moral law in Kant is taken by 'the agent's attraction to the other and what she exemplifies' (p. 13). And self-reliance becomes, then, 'the exercise not of power but of reception' (p. 212).

There is reason for minor reservation also over Norris's carefully qualified criticism of an aspect of Cavell's response to Rawls. Cavell questions the apparent freedom from reproach that assent to the 'original position' would safeguard, on the grounds, I take it, that there can be no society where one is free in this way, and its denial, albeit in ideal theory, is tantamount to a denial of the human condition. Norris's objection is precise and concerns Cavell's over-interpretation of section 73 ('Features of the Moral Sentiments') of A Theory of Justice (1971). But Rawls's treatment of moral sentiments is categorial in a way that Cavell's is not, and this blocks appreciation of the complexities of human response as realised, for example,

(c) 2019 Springer Nature Limited. 1470-8914 Contemporary Political Theory Vol. 19, S4, S239-S242 S241 
in what Cavell has to say about 'passionate utterance' and in his patient, politically pertinent examination of those Hollywood films that become such crucial reference points for his thought. It is against this wider backdrop that the salience of his resistance to the idea that a human being might be above reproach can be seen.

The importance of this goes well beyond that of a detail of textual analysis. Consider, for example, the poverty of what, in so many contexts, passes for citizenship education: emphasis is placed on the understanding of democratic institutions, on virtues of clear argument and attention to the views of others, and on a disposition of toleration, to the neglect of the weight of history, the background of injustice against which societies are almost inevitably formed. This is a repression of the political emotions in the light of which political lives are played out and consent is exacted.

Consent and constitution are themes that run throughout Norris's discussion, reflecting preoccupations in Cavell that extend, through the political, to what it is to be a human being. They extend also to American democracy's complicity with slavery and to the continuing racialized fractures in its society. Norris examines these matters with an economy and aptness that opens Cavell's thought to wider reflection, realising lines of connection from Emerson to Ralph Waldo Ellison. These are thoughts that reverberate, often underground, throughout Cavell's work.

It is in these and other ways that Norris's fine book should certainly help to redress the relative neglect of Cavell's work amongst political philosophers and theorists. In thematising the political, it takes the interpretation of Cavell's work to a new level, and it challenges the terms of political philosophy itself.

\section{References}

Norris, A. (ed.). (2006) The Claim to Community: Essays on Stanley Cavell and Political Philosophy. Stanford: Stanford University Press.

Rawls, J. (1971) A Theory of Justice. Cambridge: Harvard University Press.

Publisher's Note Springer Nature remains neutral with regard to jurisdictional claims in published maps and institutional affiliations.

Paul Standish

Centre for Philosophy of Education, University College London Institute of Education, London WC1H0AL, UK p.standish@ucl.ac.uk 